\title{
PELAYANAN PENDAFTARAN HAK ATAS TANAH
}

\author{
Hengky Barnabas, Gunawan \\ Fakultas Ilmu Sosial dan Ilmu Politik Universitas Kapuas Sintang \\ Jalan YC Oevang Oeray Nomor 92 Baning Kota Sintang \\ Email:gunawans3ub@gmail.com
}

\begin{abstract}
Abstrak: Penelitian ini menganalisis kualitas pelayanan pendaftaran tanah secara konversi sporadik di Kantor Pertanahan Nasiona Kabupaten Sintang dengan Metode Penelitian Kualitatif dan jenis penelitian Deskriptif. Hasil penelitian 1) Prosedur Pendaftran Tanah di BPN Kabupaten Sintang telah dilaksanakan sesuai dengan aturan namun prosesnnya memliiki kendala lamanya waktu dan tahapan Pendaftran tanah yang rumit bagi beberapa pemohon yang pertama kali. 2) Standar pelayanan pendaftaran Tanah cukup memberikan kenyamanan dan kemudahan informasi secara online maupun offline., fasilitas di dalam ruang tunggu cukup nyaman. 3) SDM cukup baik dan profesioanl dalam memberikan pelayanan.
\end{abstract}

Kata Kunci : Pelayanan, Pendaftaran Hak Atas Tanah

Dalam upaya memberikan pelayanan kepada masyarakat Kantor Pertanahan tidak terlepas dari tuntutan masyarakat yang ada di wilayah kerjanya untuk dapat memberikan pelayanan yang berkualitas, jauh dari citra birokrasi yang berbelit belit, transparan dan lebih memperhatikan aspek keberpihakan kepada masyarakat, sehingga tuntutan akan adanya kinerja yang berkualitas merupakan suatu kebutuhan dan keharusan. Sebagai contoh dalam pengurusan sertifikat secara sporadik cenderung kurang dipahami dan diketahui oleh masyarakat karena kurangnya sosialisasi sehingga biayanya bisa melebihi dari peraturan yang telah ditetapkan pemerintah. Berdasarkan Keputusan Menteri Pendayagunaan Aparatur Negara Nomor 63 tahun 2004 menyatakan hakekat pelayanan publik adalah memberikan pelayanan prima kepada masyarakat yang merupakan perwujudan kewajiban aparatur pemerintah sebagai abdi negara. Untuk dapat memberikan pelayanan yang memuaskan bagi pengguna layanan, penyelenggara pelayanan harus memenuhi asas-asas pelayanan sebagai berikut: transparansi, akuntabilitas, kondisional, partisipatif, kesamaan hak keseimbangan antara hak dan kewajiban. Ukuran keberhasilan penyelenggaraan pelayanan ditentukan oleh tingkat kepuasan penerima pelayanan

Keluhan masyarakat terhadap kurangnya kualitas pelayanan pada Kantor Badan Pertanahan (BPN) Kabupaten Sintang merupakan salah satu indikator yang menunjukkan belum memadainya pelayanan yang diberikan oleh aparatur birokrasi.Tuntutan dan kebutuhan masyarakat tersebut merupakan tantangan bagi birokrasi untuk dapat memberikan pelayanan yang terbaik serta untuk dapat melaksanakan fungsinya dengan baik.Untuk itu, institusi birokrasi perlu menerapkan strategi peningkatan pelayanan yang tanggap terhadap kebutuhan-kebutuhan masyarakat yang menghendaki kualitas pelayanan.
Badan Pertanahan Nasional (BPN) Kabupaten Sintang sebagai salah satu Institusi Briokrasi Pemerintah maka Penataan, pembinaan, dan pendayagunaan aparatur yang "gagap teknologi" sangat diperlukan untuk menghadapi tantangan perkembangan zaman ini untuk dapat mencapai pelayanan publik yang berkualitas sesuai dengan yang didambakan masyarakat. Dengan ini, pelayanan terhadap masyarakat benar-benar menjadi prioritas utama dan para aparat birokrasi sebagai pelayan masyarakat akan lebih mampu melayani, mengayomi, dan menumbuhkan partisipasi masyarakat, sehingga birokrasi yang baik dan sesuai dengan harapan serta aspirasi masyarakat dapat tercipta Berbagai inovasi mengenai pelayanan telah banyak dilakukan oleh sebagian besar instansi publik. Hal ini dilakukan sebagai salah satu upaya untuk mewujudkan pelayanan kepada masyarakat yang lebih baik, mudah serta terjangkau dan juga sebagai jawaban kepercayaan yang telah diberikan oleh masyarakat terhadap kinerja dari birokrasi pelayanan publik pada Badan Pertanahan (BPN) Kabupaten Pintang yang notabene selama ini mendapatkan "image" kurang memuaskan dari sebagian besar kalangan masyarakat yang mengurus pelayanan pendaftaran tanah seperti proses pengurusan yang terlalu berbelit-belit, memakan waktu yang terlalu panjang serta memakan biaya yang mahal. ditambah ulah pihak-pihak yang ingin mengambil keuntungan pada akhirnya bermuara pada pembentukan opini publik yang apatis terhadap pelayanan sertifikasi pertanahan. Hal yang dikeluhkan oleh masyarakat tersebut disebabkan karena informasi mengenai kegiatan-kegiatan pertanahan baik itu dalam hal kegiatan sertipikasi maupun program pertanahan tidak tersosialisasi dengan baik, terutama yang berkaitan dengan proses permohonan sertipikasi baik itu dalam hal kepastian dan lamanya waktu pensertipikasian tanah, persyaratan yang harus dipenuhi dan semua 
biaya-biaya yang terkait dengan dalam proses pendaftaran tanah tersebut.

Dampak dari kondisi ini meyebabkan rendahnya kesadaran masyarakat untuk mendaftarkan bidang-bidang tanahnya, Masyarakat terkesan semakin menjauh bila sudah menyangkut urusan hak atas tanah.Padahal sertifikat menjadi bagian penting menyangkut kepastian hukum atas hak milik pertanahan dari seseorang yang merupakan salah satu pintu untuk meningkatkan kegiatan perekonomian.Seperti yang diketahui bahwa pendaftaran tanah adalah bertujuan untuk memperoleh kepastian hukum dan kepastian hak terhadap pemegang hak-hak atas tanah. Dengan pendaftaran tanah diharapkan bahwa seseorang akan merasa aman tidak ada gangguan atas hak yang dimilikinya.

Oleh karena itu, Rumusan masalah dalam penelitian ini adalah bagaimana kualitas pelayanan Pendaftaran Hak Atas Tanah di Kantor Badan Pertanahan Nasional (BPN) Kabupaten Sintang dengan ruang lingkup: Prosedur Pendaftaran Tanah, Standar Pelayanan Pendaftaran Tanah, dan Sumber Daya Manusia.

Sistem pendaftaran tanah mempermasalahkan apa yang didaftar, bentuk dan penyimpanan dan penyajian data yuridisnya serta bentuk tanda bukti haknya. Menurut Boedi Harsono (2003:77) sistem pendaftaran tanah ada 2 (dua) macam, yaitu sistem pendaftaran akta (registration of deeds) dan sistem pendaftaran hak (registrationof title). Baik dalam sistem pendaftaran akta maupun sistem pendaftaran hak,setiap pemberian atau penciptaan hak baru, peralihan serta pembebanannya dengan hak lain, harus dibuktikan dengan suatu akta.Untuk pendaftaran hak dan perubahan- perubahan yang terjadi disediakan suatu daftar isian (register), atau disebut juga buku tanah. Buku tanah ini disimpan di kantor pertanahan dan terbuka untuk umum. Dalam sistem ini pejabat pendaftaran tanah bersikap aktif dan sebagai tanda bukti hak diterbitkan Sertifikat yang merupakan salinan register (registration of title).

Menurut Boedi Harsono (2003:80) "sistem pendaftaran yang digunakan di Indonesia adalah sistem pendaftaran hak (registration of title), sebagaimana digunakan dalam penyelenggaraan pendaftaran tanah menurut Peraturan Pemerintah Nomor 10 Tahun 1961". Hal tersebut tampak dengan adanya buku tanah sebagai dokumen yang memuat data yuridis dan data fisik yang dihimpun dan disajikan serta diterbitkannya sertifikat sebagai surat tanda bukti yang terdaftar. Pembukuan dalam Buku Tanah serta pencatatannya pada surat ukur tersebut merupakan bukti, bahwa hak yang bersangkutan beserta pemegang haknya dan bidang tanahnya yang diuraikan dalam surat ukur secara hukum telah didaftar menurut Peraturan Pemerintah Nomor 27 Tahun 1997 Pasal 29.

Dalam Peraturan Pemerintah Nomor 24 Tahun 1997 pasal 2 tentang Pendaftaran Tanah dinyatakan bahwa pendaftaran tanah dilaksanakan berdasarkan: asas sederhana asas aman' asas terjangkau asas mutakhir dan asas terbuka. Dalam Peraturan Pemerintah No.24 Tahun 1997 Tentang Pendaftaran Tanah pada pasal I butir I yang dimaksud denganPendaftaran Tanah adalah rangkaian kegiatan yang dilakukan oleh pemerintah secarah terus-menerus, berkesinambungan dan teratur, meliputi pengumpulan, pengolahan, pembukuan dan penyajian serta pemeliharaan data fisik dan yuridis, dalam bentuk peta dan daftar, mengenai bidang-bidang tanah dan satuan rumah susun, termasuk pemberian sertifikat sebagai surat tanda bukti haknya bagi bidang-bidang tanah yang sudah ada haknya dan hak milik atas satuan rumah susun serta hak-hak tertentu yang membebaninya.

Taufiqurokhman dan Evi (2018:71) "pelayanan yang diberikan oleh instansi pemerintah kepada masyarakat, pelayanan untuk masyarakat tidak terlepas dari masalah kepentingan umum, yang menjadi asal usul timbulnya pelayanan umum tersebut. Dengan kata lain, terdapat korelasi antara kepentingan umum dengan pelayanan umum". Dari definisi tersebut dapat disimpulkan bahwa pada hakikatnya pelayanan itu adalah serangkaian kegiatan yang diberikan seseorang kepada orang lain, yang merupakan suatu proses untuk memuaskan orang lain.

Menurut Sudaro dalam Sinambela (2006:18) menyebutkan ada beberapa standar pelayanan yaitu sebagai berikut:Prosedur pelayanan, Waktu penyelesaian, Biaya pelayanan, Produk pelayanan, Saran dan prasarana, dan Kompetensi petugas pemberi pelayanan.

Pendayagunaan Aparatur Negara Nomor 63/KEP/M.PAN/7/2003 menjelaskan 14 unsur yang menjadi tolak ukur berkualitasnya suatu pelayanan di suatu instansi atau lembaga, unsurunsur itu antara lain : Prosedur Pelayanan, Persyaratan Pelayanan, Kejelasan Petugas Pelayanan, Tanggung Jawab Petugas Pelayanan, Kemampuan Petugas Pelayanan, Kecepatan Pelayanan, Keadilan Mendapatkan Pelayanan, Kesopanan dan Keramahan Petugas, Kewajaran Biaya Pelayanan, Kepastian Biaya Pelayanan, Kepastian Jadwal Pelayanan, Kenyamanan Lingkungan, Keamanan Pelayanan,

Konsep standar pelayanan sebagaimana diuraikan tersebut tentunya mengarah pada suatu tatanan pelayanan yang prima dan menuju pada kualitas yang maksimal sesuai dengan peraturan yang berlaku serta mudah dalam implementasinya.pelayanan prima merupakan 
Hengky, Gunawan, Pelayanan Pendaftaran Hak Atas Tanah 263

tuntutan reformasi birokrasi. Menurut Sinambela, (2006:6) mengatakan bahwa kualitas pelayanan prima tercermin dari TransparansiAkutabilisas, Kondisional, Partisifatif, dan Keseimbangan.

Standar pelayanan yang dilaksanakan oleh pemerintah mengacu pada Peraturan Pemerintah Nomor 65 Tahun 2005 Tentang Pedoman Penyusunan Dan Penerapan Standar Pelayanan Minimal pada Bab II pasal 2 ayat (2) yang berbunyi "SPM disusun dan diterapkan dalam rangka penyelenggaraan urusan wajib Pemerintahan Daerah Provinsi dan Pemerintahan Daerah Kabupaten/Kota yang berkaitan dengan pelayanan dasar sesuai dengan peraturan perundang-undangan".

AarjeTehupeiory (2012:6) "Untuk Mewujudkan Jaminan kepastian Hukum di bidang pertanahan ada 2 (dua) hal yang harus di perhatikan yaitu adanya hukum yang tertulis dan penyelenggara pendaftaran tanah". Dimensi kualitas pelayanan Dalam peraturan Kepala Badan Pertanahan RI Nomor 1 tahun 2010 tentang Standar Pelayanan Dan Peraturan Pertanahan disebutkan bahawa kelompok pelayanan terdiri dari Pendaftran tanah pertama kali, Pemeliharaan Data Pendaftaan Tanah, Pencatatann dan informasi pertanahan, Pengukiran bidang tanah, Pengaturan dan penataan, danPengelolaan pengaduan.

Dalam rangka pelaksanaan kegiatan pendaftaran tanah Besarnya dan cara pembayaran biaya-biaya diatur dengan Peraturan Pemerintah tersendiri, demikian isi Pasal 61 Peraturan Pemerintah Nomor 24 Tahun 1997, adapun yang dimaksud dengan Peraturan Pemerintah tersendiri" yaitu Peraturan Pemerintah No. 128 Tahun 2015 tentang Jenis dan Tarif atas Jenis Penerimaan Negara Bukan Pajak yang berlaku pada Kementrian Agraria dan Tata Ruang/ BPN. Atas permohonan yang bersangkutan, Menteri atau pejabat yang ditunjuknya dapat membebaskan pemohon dari sebagian atau seluruh biaya pendaftaran, jika pemohon dapat membuktikan tidak mampu membayar biaya tersebut.

Fx Sumarja (2015: 107) Biaya-biaya dalam rangka pelaksanaan kegiatan pendaftaran tanah, meliputi biaya untuk:Pelayanan pendaftaran tanah, Pelayanan pemeriksaan tanah, Pelayanan informasi tanah, Pelayanan konsolidasi tanah secara swadaya, Pelayanan redistribusi tanah secara swadaya, Pelayanan penetapan hak atas tanah, Pelayanan pendaftaran tanah, meliputi biayabiaya sebagai berikut, Pelayanan pengukuran dan pemetaan bidang tanah, Pelayanan pendaftaran tanah untuk pertama kali, dan Pelayanan pemeliharaan data pendaftaran tanah.

Sumber Daya Manusia merupakan suatu hal yang sangat penting bagi setiap organisasi sehingga perlu dikelola, diatur dan dimanfaatkan agar dapat berfungsi secara produktif untuk mencapai tujuan organisasi.Demikian pula sumber daya manusia yang dimiliki oleh suatu organisasi perlu dikelola secara profesional agar terwujud keseimbangan antara kebutuhan pegawai dengan tuntutan dan kemampuan organisasi. Sumber Daya Manusia (SDM) yang baik di dalam sebuah organisasi pelayanan publik akan menjadi aset yang dapat menghasilkan pekerjaan-pekerjaan pelayanan publik yang baik, sehingga akan melahirkan image yang baik pula terhadap organisasi pelayanan publik.

Sumber daya manusia sangat penting dalam dinamika pelayanan pada masyarakat karena dinamika perkembangan masyarakat cenderung semakin kompleks, menurut Hendry (2001:2) "istilah sumber daya manusia adalah merujuk kepada orang-orang di dalam organisasi". Adapun alasan pentingnya peran strategis manusia menurut Siagian (2009: 178-179) yaitu:1.Manusia sebagai penggerak benda-benda mati menjadi "alat yang hidup (alat-alat produksi, fasilitas kerja, 2.Manusia mempunyai karakteristik yang tidak dimiliki oleh suber daya lain, seperti harkat dan martabatnya yang mutlak perlu diakui, akal dan nalarnya dalam berpikir, kepribaian dan kemampuan serta motivasinya. 3.Predikat" yang menggambarkan manusia merupakan mahluk yang kompleks. 4.Perkembangan pesat ilmu pengetahuan berdampak pada tidak konsistenya manusia yang disebabkan oleh berbagai faktor seperti jenis pekerjaan, suasana kerja, bakat, minat dan persepsinya tentang kepentingan.

Selanjutnya menurut Elton dalam Hendry (2001:9) "produktivitas kerja karyawan tidak hanya dipengaruhi oleh cara pekerjaan dirancang dan bagaimana mereka diberikan imbalan secara ekonomis, tetapi juga oleh faktor-faktor lain seperti faktor sosial, psikologis, termasuk pemberdayaan dan pendayagunaan sumber daya manusia".

Menurut Pasolong (2008:103) "pada masa mendatang manajemen SDM hendaknya memperhatikan prinsip-prinsipCivil Services yang semakin medapat perhatian semua pihak". Berlandaskan pada argumen tersebut, sudah menjadi keharusan dan bahkan menjadi kebutuhan bagi organiasi pemerintahan dalam meningkatkan pelayanan kepada masyarakat secara profesional, cepat dan memuaskan.Kemampuan di dalam kamus Bahasa Indonesia berasal dari kata "mampu" yang berarti bisa atau sanggup.Sedangkan kemampuan diartikan sebagai kesanggupan, kecakapan, dan kekuatan yang menunjukan kapasitas fisik dan mental dari seorang pegawai untuk melakukan sesuatu. Menurut Swasto Bambang dalam Musafir (2007:5) kemampuan memiliki tiga indikator yakni pengetahuan, keterampilan, dan sikap: 
Ciri-ciri individu yang memiliki kemampuan dan kreatif menurut Kennon dan Baron, dalam harbani pasolong (2010: 98) antara lain : lebih menunjukan sifat dewasa secara emosional dan peka dalam menangkap masalah dari suatu situasi, dapat memenuhi kebutuhan sendiri, tidak tergantung pada orang lain dan percaya diri sendiri, mampu menguasai diri sendiri, penuh keberanian bermakna, dan panjang akalnya.Dalam hal ini Sudarwan Danim (2015:45) mengklasifikasikan indikator dari ketiga kualitas tersebut yaitu :Kualitas fisik dan kesehatan, Kualitas intelektual (pengetahuan dan ketrampilan), dan Kualitas spiritual.

Menurut Winarno dalam (Wisakti 2008) bahwa perintah implementasi mungkin diteruskan secara cermat, jelas dan konsisten, tetapi jika para pelaksana kekurangan sumber-sumber yang diperlukan untuk melaksanakan kebijakankebijakan, maka implementasi ini pun cendrung kurang efektif.Dengan demikian sumber-sumber dapat merupakan faktor yang penting dalam melaksanakan kebijakan publik. Winarno dalam (Wisakti 2008) mengungkapkan bahwa sumbersumber yang mendukung kebijakan yang efektif terdiri dari jumlah staf yang mempunyai ketrampilan yang memadahi serta jumlah yang cukup, kewenangan, informasi dan fasilitas.

Berdasarkan teori diatas untuk mengukur sumber daya maka fenomena yang digunakan adalahKemampuan sumber daya manusia dalam pelaksanaan kebijakan dan Penyediaan Fasilitasfasilitas yang mendukung kebijakan

\section{METODE PENELITIAN}

Penelitian ini menggunakan Metode Penelitian Kualitatif dan jenis penelitian Deskriptif.Singarimbun,(1989:4) Metode Deskriptif dimaksudkan untuk melakukan pengamatan dan pengukuran yang cermat terhadap fenomena sosial tertentu. Dalam hal ini penelitian mengembangkan prinsip dan menghimpun fakta namun tidak melakukan pengujian hipotesis. Menurut Ali (1997:57), "penelitian deskriptif melukiskan secara tepat sifat-sifat suatu individu/keadaan, suatu gejala dan sebagainya yang merupakan objek penelitian". Menurut Surachmad (1990:140), "Metode deskriptif memusatkan diri pada pemecahan masalah yang ada (actual) dan berusaha mengumpulkan data atau fakta yang kemudian disusun, dijelaskan, dan dianalisa." Subjek penelitian dalam Penelitian ini adalah:Kepala Badan Pertanahan Nasional ( BPN) Kabupaten Sintang, Kepala Seksi Hak Tanah dan Pendaftran Tanah BPN Kabupaten Sintang, dan Warga Masyarakat yang melakukan Pendaftaran Tanah di BPN Kabupaten Sintang

Menurut Nasir (1988:211) “pengumpulan data adalah prosedur yang sistematik dan standar untuk memperoleh data yang diperlukan”. Tehniktehnik pengumpulan data sebagai berikut :Pengamatan/Observasi, Wawancara atau interview, dan Studi Dokumentasi.

Dalam penelitian ini peneliti menggunakan alat alat pengumpulan data berupa Pedoman Wawancara, Panduan Observasi dan Untuk memperoleh Dokumentasi digunakan alat bantu fotocopy, HP kamera,printer, dan lain-lain yang berhubungan denganPelayanan Pendaftaran Hak Aatas Tanah di Badan Petanahan Nasional Kabupaten Sintang. Teknik analisis data yang digunakan adalah teknik analisis kualitatif, yakni data yang terkumpul baik data primer maupun data sekunder diklasifikasikan sesuai dengan jenis data dan kemudian dideskripsikan ataupun dengan menggunakan ungkapan-ungkapan kalimat sebagai interprestasi atau penafsiran dari indikator penelitian yang diajukan untuk selanjutnya dibuat suatu kesimpulan.

\section{HASIL PENELITIAN DAN PEMBAHASAAN \\ Prosedur Pendaftaran Tanah}

Prosedur Pendaftran Tanah dalam tahapan-tahapannya BPN Kabupaten Sintang selalu menggunakan aturan tentang pendaftaran tanah yang sudah ditetapkankarena hal ini memang dibuat untuk mensamaratakan proses pendaftaran tanah diseluruh Indonesia. Pemohon juga dapan mengunakan simulasi pendafatarn tanah yang ada di webside BPN RI. Hal tersebut sudah disosialiasikan kepada masyarakat yang ingin mengajukan Permohonan Pendaftaran Tanah dan tidak, hal ini juga dapat di lihat dalam webside BPN Kabupaten Sintang. Biasanya keterlambatan penerbitan sertipikat tanah disebabkan karena kurangnya persyaratan yang dipenuhi oleh para pemohon..Prosedur pendaftran tanah BPN Kabupaten Sintang dilaksanakan sesuai dengan aturan yang sudah ditetapkan dan kemudian berupaya untuk memberikan kemudahan.

Pada proses masukan, pemohon sertifikat tanah harus menjalani serangkaian aktifitas, prosedur atau proses mulai dari tahap yang meliputi: pemohon mendatangi bagian Pendaftaran dan Informasi, menyerahkan syarat-syarat permohonan sertipikat berupa surat permohonan, identitas pemohon, bukti tertulis yang membuktikan adanya hak atas tanah, Foto copy Surat Pemberitahuan Pajak Terutang (SPPT). Setelah seluruh kelengkapan telah dipenuhi, dilanjutkan pada proses A yaitu berkas dimasukkan ke bagian Pengukuran dan Pemetaan untuk dilakukan pengukuran letak dan batas tanah oleh petugas ukur. Kemudian pada proses B dilakukan pengecekan letak dan batas tanah telah disahkan oleh petugas, berkas dilanjutkan ke bagian 
Pemeriksaan untuk diteliti dan diproses lebih lanjut baik secara fisik maupun yuridis. Tahap proses $\mathrm{C}$ selanjutnya diadakan pengumuman apakah sertipikat yang diajukan disetujui oleh pihak pertanahan ataupun tidak. Tahap akhir berupa keluaran yaitu penerbitan sertipikat dimana pemohon dapat mengambil sertipikat yang diterbitkan di loket pengambilan produk. Untuk biaya ini pada tentu juga disesuaikan dengan aturan yang berlaku dan sebelum mengurus akan di jelaskan kepada masyarakat yang melakukan pendaftaran tanah. Proses tentu sebetulnya memberi kemudahan namun mememang ini berlangsung secara berurutan dimana seorang pemohon belum bisa melakukan permohonan pengukuran tanah jika belum ada berkas masuk ke Kantor Pertanahan, begitu seterusnya.

Untuk proses pembuatan sertfikat ini meskipun terdengar cukup rumit bagi masyarakat yang belum pernah mengurus pembuatan sertifikat, masih menjadi keresahan lamanya waktu pembuatan sertfikat dan biaya yang dikeluarkan kadang masih belum jelas, karana setiap orang kadang bisabeda biayanya. Jadi masayarakat masih memiliki keresahan terutama masalah lamanya waktu dan biaya.

Prosedur pendaftaran tanah di Kantor BPN Kabupaten Sintang sebagai berikut: 1) Pemohon mendatangi bagian pendaftaran dan informasi, menyerahkan syarat-syarat, 2) Diajukan secara individual atau massal oleh pihak yang berkepentingan, yaitu pihak yang berhak atas bidang tanah yang bersangkutan atau kuasanya. Permen Agraria/Kep BPN 3/1997 pihak yang berkepentingan adalah pemegang hak dan pihak lain yang mempunyai kepentingan atas bidang tanah.3) Pembuatan Peta Dasar Pendaftaran, menjadi dasar pembuaan peta pendaftaran. Untuk kepentingan ini BPN menyelenggarakan pemasangan, pengukuran, pemetaan dan pemeliharaan titik2 dasar teknik nasional di setiap kabupaten/kota. 4) Penetapan Batas BidangBidang Tanah Dilakukan dengan memperhatikan batas2 bidang tanah yang telah terdaftar dan SU atau GS yang bersangkutan, jika ada yang tidak sesuai dengan keadaan yang sebenarnya maka sedapat mungkin disetujui oleh pemegang hak yang berbatasan Guna penetapan batas2, maka BPN juga membuat berita acara mengenai dilakukannya pengukuran. 5) Pengukuran dan Pemetaan Bidang Tanah dan Pembuatan Peta Pendaftaran, 6) Pembuatan Daftar Tanah, Bidang tanah yang sudah dipetakan atau diberi nomor pendaftarannya dibukukan dalam daftar tanah, 7) Pembuatan SU, untuk keperluan pendaftaran haknya, 8) Pembuktian Hak Baru yakni HAT baru dengan: penetapan pemberian hak oleh pejabat atau asli akta PPAT, HPL dengan penetapan pemberian
HPL oleh pejabat yang berwenang, Tanah Wakaf dengan akta Ikrar Wakaf, Hak Milik Atas Satuan Rumah Susun dengan akta pemisahan, HT dengan APHT, 9) Pembuktian Hak lama Pasal. Berasal dari konversi hak, dibuktikan dengan bukti tertulis, keterangan saksi, jika tidak tersedia alat pembuktian yang lengkap dapat dilakukan dengan pernyataan penguasaan fisik selama 20 th berturut2, dengan syarat: Penguasaan dilakukan dengan itikad baik secara terbuka dikuatkan oleh kesaksian orang yang dapat dipercaya (umumnya oleh lurah), Tidak ada permasalahan dalam hal penguasaan baik sebelum maupun setelah pengumuman. 10) Pengumuman Hasil Penelitian Yuridis dan Hasil Pengukuran, jika ada pihak yang berkeberatan, maka disarankan untuk menyelesaikan secara musyawarah, jika tidak berhasol, maka diselsaikan di pengadilan. 11) Pengesahan Hasil Pengumuman , disahkan dalam suatu berita acara sebagai dasar untuk: Pembukuan HAT dalam buku tanah, Pengakuan HAT, Pemberian HAT, 12) Pembukuan Hak, Pembukuan dalam buku tanah serta pencatatannya pada surat ukur merupakan bukti bahwa hak yang bersangkutan beserta pemegang haknya dan bidang tanah yang diuraikan dalam surat ukur secara hukum telah terdaftar. Jika ada yang belum lengkap dibuat catatan yang akan dihapus bila, telah dilengkapi atau dalam jangka waktu 5 th tdk ada pengajuan gugatan ke pengadilan. Jika ada sengketa, maka akan dibuat catatan, yang akan hapus jika telah ada kesepakatan damai atau 90 hari setelah terima pemberitahuan tidak diajukan gugatan di pengadilan. 13) Penerbitan sertifikat . Dilakukan untuk kepentingan pemegang hak yang bersangkutan, jika ada catatan 2 maka penerbitan akan ditangguhkan Individual di TTD Kkn, Massal di TTD Kepala seksi pengukuran dan pendaftaran tanah.

Prosedur pendaftaran tanah di BPN Kabupaten Sintang sudah cukup baik, sehingga hal ini tentu dapat meningkatkan keingain masyarakat untuk mendaftarkan tanahnya ke BPN Kabupaten Sintang. Meskipun beberapa masyarakat mengakat bahwa prosedur pendafatran tanah ini memang sulit bagi masayakat yang tidak memahami proses atau tahapan-tahapan pendaftran tanah dan lamanya waktu yanng diperlukan untuk mengurus sertifikat tanah terbilang cukup lama dan biaya yang di anggap masih belum jelas.Permasalah seperti ini tentu harus segera untuk di atasi guna meningkatan kulitas pelayanan dan kepercayaan masyarakat pada kinerja di Kantor BPN Kabupaten.Sintang.

Melalui Laporan Kinerja Kantor Pertanahan Kabupeten Sintang Tahun 2019 BPN menyebutkan ada beberapa permasalahan strategis pertanahan dalam proses pendaftran tanah yang di lakukan yakni Rendahnya cakupan peta dasar, 
Kurangya SDM pengukuran, Sistem Informasi Pertanahan yang belum memadai, Tanah Adat dan tanah Ulayat, dan Jumlah bidang tanah yang belum terdaftar.

Jika diperhatikan pada keseluruhan permasalahan yang disampaikan oleh BPN Kabupaten Sintang dari poin pertama sampai pada poin kelima merupakan permasalahan yang dapat mengahambat penyelesaian tahapan-tahapan pendaftaran tanah, sehingga menyebabkan menumpuknya berkas-berkas permohonan Pendaftaran Tanah. Apabila hal ini terus berlangsung dalam waktu yang lama tentu akan mengurangi kepercayaan masyarakat dan memunculkan isu-isu social yang buruk terhadapat kinerja di Kantor BPN Kabupaten Sintang.

\section{Standar Pelayanan Pendaftaran Tanah}

Standar pelayanan tentu sudah disesuiakan dengan praturan yang ada yaitu PERKBPN nomor 1 tahun 2010.BPN Sintang berupaya mepermudah serta memberi kenyaman kepada masyarakat yang melakukan pendaftran tanah dengan segala fasilitas yang kami sediakan.Kantor BPN Kabupaten Sintang dalam aktivitas harianya selalu menerimma masukan dan saran baik melaui online maupun secara langsung melalui kotak saran yang kita miliki. Kita juga memiliki loket pelayan informasi dimana masyarakat bisa bertanya tentang proses pendaftaran tanah maupuan kendala yang di hadapi dalam pendaftran tanah.

Sebelum pendaftran tanah di Kantor BPN Kab Sintang memiliki loket pelayanan informasi yang kemudian akan menjelaskan persyaratan dan proses pendataran tanah dan mengarahkan masyarakat yang akan melakukan Pendaftran tanah untuk membantu masyarakat. BPN Sintang menginformasikan pendaftaran tanah melaui media sosial seperti youtube, facebook dan Instagram mengikuti pemkembangan zaman. Untuk waktu pelaksanaan kami juga tentu menyesuaikan, apalagi sekarang sudah ada aplikasi sentuh tanahku, dimana masyarakat, jadi masyarakat dapat melihat sudah sejauh mana proses pendaftaran tanah. Kantor BPN Kabupaten Sintang juga memiliki tempat untuk mengetahiu kepuasan pelayanan yang diberikan tentang pendaftran tanah, kami juga memiliki layanan penganduan untuk masyarakat yang mesara tanah saya sudah di daftrakan tahun lalu kenapa belum jadi-jadi, nah itu bisa langsung di tanyakan, secara online juga sudah tersedia. Lebih mudah sekarang kita juga memeiliki simulasi online untuk memudahkan msayarakat mengatahui proses pendaftran tanah.

Dari penyampain di atas dalam Standar Pelayanan Pendafatran tanah BPN Kabupaten Sintang selalu memberi kemudahan dimana terdapat loket layanan informasi yang disediakan sehingga sangat membantu dalam proses pendaftran tanah. Dengan adanya PERKBPN nomor 1 tahun 2010 tentang SOPP yang menjadi acuan bagi BPN KabupatenSintang dalam memberikan pelayanan semaksimal mungkin, terlebih lagi dalam menginformasikan tentang pendaftaran tanah melaui sosial media yang terbilang cukup efektif karena masyarakat dapat mengakses berbagai persyaratan dan biaya pendaftaran tanah melalui rumah.

Persyaratan untuk untuk melakukan Pendaftaran tanah secara Konversi Sporadik di Kantor BPN kabupaten Sintang yakni Formulir permohonan yang sudah diisi dan ditandatangani pemohon atau kuasanya di atas materai cukup, Surat Kuasa apabila dikuasakan, Fotocopy identitas (KTP, KK) pemohon dan kuasa apabila dikuasakan, yang telah dicocokkan dengan aslinya oleh petugas loket, Bukti pemilikan tanah/alas hak milik adat/bekas milik adat, Foto copy SPPT PBB Tahun berjalan yang telah dicocokkan dengan aslinya oleh petugas loket dan penyerahan bukti SSB (BPHTB), Melampirkan bukti SSP/PPh sesuai dengan ketentuan.

Pelayanan di kantor BPN kabupaten Sintang cukup baik dengan fasilitas yang disediakan dan kejelasan tentang persyaratan serta informasi yang dibagikan kepada masyarakat.dengan baiknya standar pelayanan yang berikan dapat mengimbangi isu-isu buruk terhadap kinerja di kantor BPN Kabupaten Sintang.

\section{Sumber Daya Manusia}

Faktor yang mempengaruhi keberhasilan mencapai tujuan salah satunya yakni kemampuan sumber daya manusia.Sumber daya manusia sangat penting dalam dinamika pelayanan pada masyarakat karena dinamika perkembangan masyarakat cenderung semakin kompleks.

Pegawai di kantor BPN Kabupaten Sintang selalu menjalankan tugas sesuai dengan posisi masing-masing, dan tentu sudah mematuhi aturan yang ada, baik yang di kantor dan yang bagian lapangan. Kemudian petugas juga tentu melaksanakan prosedur yang telah ditetapkan dalam memberikan pelayanan.Dalam hal ini setiap petugas di awasi kode etik juga mematuhi Edaran kepala BPN Kabupaten Sintang.Namun pada petugas lapangan tidak diawasi hanya di awasi oleh kode etik.Petugas BPN Kabupaten Sintang masih mengalami kekurang petugas ukur. Kekuranga petugas ukur disebabkan pemberhentian tidak terhormat karena melakukan pungli, sehingga hal ini membuat buruk nama BPN Kabupaten Sintang dan terutama masyarakat.

Kantor Badan Pertanahan Nasional Kabupaten Sintang dalam menyelenggarakan tugas dan fungsinya didukung oleh SDM sebanyak 29 orang ASN, terdiri dari 17 pejabat struktural dan 
Hengky, Gunawan, Pelayanan Pendaftaran Hak Atas Tanah 267

12 jabatan fungsional umum(JFU), dan dari jumlah JFU tersebut sebagai petugas ukur sebanyak 5 orang. Selain ASN, Kantor Pertanahan Kabupaten Sintang juga di bantu dengan 30 orang PPNPN.

Proporsi kompetensi ideal untuk petugas ukur diharapkan $30 \%$ dari jumlah pegawai.Saat ini jumlah sumber daya manusia petugas ukur masih sangat kurang, yaitu baru mencapai sekitar 5 orang dari jumlah pegawai keseluruhan sebanyak 29 orang. Jika melihat kepada jumlah tanah yang belum terdaftar sebanyak 606.350 bidang dan yang sudah sebanyak 25.818 bidang dan target pada tahun 2020 sebanyak 580.532 bidang maka hal ini tentu menjadi penghambat dalam proses pencapain target bidang tanah pada tahun 2020.

Dari penyampain diatas dapat disimpulkan bahwa sumberdaya manusia atau dalam hal ini adalah petugas dan pegawai yang berada di kantor BPN Kabupaten Sintang terbilang sangat disiplin dalam menjalankan tugas masing-masing. Dengan adanya surat edaran kepala kantor dan evakuasi setiap bulan tentu dapat selalu memberi kemajuan dalam bidang sumber daya manusia.

Dapat disimpulkan bahawa sumber daya manusia di kantor BPN Kabupaten Sintang memiliki kualitas yang bagus dalam menjalankan tugasnya. sehingga memberikan kenyamanan bagi penerima pelayanan. Berdasarkan hasil obsesrvasi, pegawai kantor BPN Kabupaten Sintang sangat tepat waktu dan sangat disiplin dalam menjalankan tugasnya, hal ini terlihat dalam keseriusan petugas dalam memberi pelayanan. Namun yang menjadi permasalahan saat ini adalah kekuranagan petugas ukur, yang mana dapat pemperlambat proses penanganan.

\section{KESIMPULAN DAN SARAN}

Prosedur Pendaftran Tanah di BPN Kabupaten Sintang telah dilaksanakan sesuai dengan aturan yang ditetapkan namun dalamprosesnnya memiliki kendala berkaitan dengan lamanya waktu untuk proses dan tahapan Pendaftran tanah yang rumit bagi beberapa pemohon yang pertama kali melakukan pendaftaran tanah. Standar pelayanan pendaftran Tanah yang ada di BPN Kabupaten Sintang bisa memberikan kenyamanan dan kemudahan informasi secara online maupun offline sehingga pemohon dapat mengakses info lebih mudah.Di samping itu pelayanan di dalam ruang tunggujuga memberi kenyaman kepada penerima pelayanan dengan semua fasilitas yang disediakan. Sumber Daya Manusia dalam hal ini adalah pegawai kantor BPN Kabupaten Sintang dinilai cukup baik dan profesioanl dalam memberikan pelayan kepada penerima pelayanan sehingga dapat memunculkan citra positif bagi BPN Kabupaten Sintang
Beberapa hal yang dapat disarankan : 1 . Prosedur Pendaftran Tanah dapat dikatakan rumit bagi sebagian masyarakat sehingga diperlukannya sosialisasi tentang tahapan-tahapan Pendaftran Tanah dan memprioritaskan perhatian perbaikan kualitas pelayanan pada ketepatan waktu pelayanan dimana pihak petugas diharapkan untuk lebih tepat waktu dalam memulai kegiatan pelayanan. 2.Meningkatkan kualitas pelayanan pendaftaran tanah dengan memprioritaskan perhatian perbaikan kualitas pelayanan sehingga menumbuhkan kepercayaan para pemohon pada petugas terhadap ketuntasan dalam memberikan pelayanan dengan selalu memberitahukan proses kegiatan pensertipikatan tanah dengan baik.3.Diharapkan untuk menambah petugas ukur, agar dapat mempercepat proses penyelesai pendaftran tanah sehingga persoalan lamanya waktu dapat teratasi dan terwujudnya kepuasan bagi masing-masing pemohon sertipikat tanah.

\section{DAFTAR PUSTAKA}

Arikunto, 2000, Majajemen Penelitian, Jakarta: Rineka Cipta Risman

,2006, Prosedur Penelitian Suatu Pendekatan Praktek, Jakarta : PT

Boedi Harsono 2003, Hukum Agraria Indonesia: Sejarah Pembentukan UUPA Isi danPelaksanaannya, , Jakarta: Djambatan,,

Faisal,S. 2001. Format-Fornat Penelitian Sosial. Jakarta : PT. Raja Grafindo persada

Hasibuan, Melayu, SP. 2006. Manajemen Dasar; Pengertian Dan Masalah.Jakarta : PT. Bumi Aksara.

Hendry, S. 2001. Manajemen SDM. Jakarta : STIE YKPN.

Luwihono. Slamet 2012. Konsep Dan Mekanisme Pelayanan Publik. Makalah Disampaikan pada "Pelatihan Partisipasi Warga dalam Pengelolaan Pelayanan Publik Dasar" yang diselenggarakan oleh Yayasan Indonesia Sejahtera (YIS) pada tanggal 30 November 2006 di Wisma "ASRI" Tawangmangu.

Mahmoedin. 1995, Etiket Pelayanan BankJakarta : PT. Gunung Agung,

Moenir, .A.S. 1998.Manajemen Pelayanan Umum Di Indonesia. Jakarta.

Bumi Aksara, Jakarta. 
268 . Fokus, Volume 18, Nomor 2, September 2020, hlm. 261 - 269

Nasir, M. 1988. Metode PenelitianJakarta : Ghalia Pasolong Harbani,2010. Teori Administrasi Publik. Bandung : ALFABETA

Poerwadarminta, WJS. 2003. Kamus Umum Bahasa Indonesia.Jakarta : Balai Pustaka.

Siagian, Sondang.P. 2007. Administrasi Pembangunan (Konsep, Dimensi dan Strateginya) .Cetakan ke Tujuh.Jakarta : Bumi Aksara.

Sinambela,lijan Poltak, 2006.Reformasi Pelayanan Pubik: Teori,Kebijakan Dan Implementasi, Jakarta: Bumi Aksara

Singarimbun, Masri dan Sofian Effendi, 1998, Metode Penelitian Survei, LP3ES, Jakarta.

Sudarwan Danim, 2015. Transpormasi Sumber Daya Manusia, jakarta: Bumi Aksara,

Sumarja,Fx, 2015. Hukum Pendaftaran Tanah, Edisi Revisi. Bardar Lampung: Universitas Lampung

Supriadi, , 2009. Hukum Agraria , Jakarta: Sinar Grafika, ,

Surachmad, Winarno, 1990, Dasar dan Teknik Research, CV Tarsito, Bandung Taufiqurokhman dan evi. 2018.Teori,Perkembangan Dan Manajemen Pelayanan Publik Tanggerang selatan:UMJ PRESS

Tehupeiory, Aarje, 2012, Pentingnya Pendaftaran Tanah,Bogor:Raih Aksa Sukses (penebar Swadaya Grup)

Tjiptono, Fandy. 2004. Pemasaran Jasa, Bayu Media Malang

Urip Santoso, 2012. Hukum Agraria, Edisi Pertama,Jakarta: Kencana Prenada Media Group

Yani, Mulia. 2000. Mekanisme dan Strategi Pelayanan Birokrasi. Jakarta : Bumi Aksara.

\section{Jurnal}

Bambang, Eko Muljono, 2016. Pendaftaran Tanah Pertama Kali Secara Sporadik Melalui Pengakuan Hak.
JurnalUnivestitas Islam Lamongan, Volume 4, no 1, Januari

Herman,W.,Hakim,D.,\&Hutagol,M.P. 2016. Analisis kepuasan Masyarakat terhadap kualitas pelayanan dalam pendaftaran Tanah pertama kali pada Kantor Badan Pertanahan Kabupaten Bogor. Jurnal ilmu keluarga \& konsumen, volume 9, Edisi 1, 65-75

Mira Novana Ardani 2019. Pelaksanaan Kegiatan Pendaftaran Tanah Sistematis Lengkap dalam Rangka Mewujudkan Pemberian Kepastian Hukum. Jurnal Gema Keadilan (ISSN: 0852-011).Volume 6, Edisi III, Oktober - November.

Peraturan Perundang-Undangan Undang-Undang Dasar 1945

Negara Republik Indonesia,2009. UndangUndang Nomor 25 Tahun 2004 Tentang Pelayanan Publik.

Negara Republik Indonesia, 2008. UndangUndang No. 9 Tahun 2018 tentang Penerimaan Negara Bukan Pajak

Negara Republik Indonesia, 2005. Peraturan Pemeruntah Nomor 65 Tahun 2005 Tentang Pedoman Penyusunan dan Penerapan Standar Pelayanan Minimal

Negara Republik Indonesia , 1997. Peraturan Pemerintah No. 24 Tahun 1997 tentang Pendaftaran Tanah

Negara Republik Indonesia,2015.Peraturan Presiden Nomor 20 Tahun 2015 tentang Badan Pertanahan Nasional

Negara Republik Indonesia, 1997.Peraturan Menteri Agraria/Kepala Badan Pertanahan Nasional No. 3 Tahun 1997 tentang Peraturan Pelaksanaan PP Nomor 24 Tahun 1997 tentang Pendaftaran Tanah

Negara Republik Indonesia, 2010.Peraturan Kepala Badan Pertanahan Nasional Republik Indonesia Nomor I Tahun 2010 tentang Standar Prosedur Operasi Pengaturan Dan Pelayanan (SPOPP) Pertanahan

Negara Republik Indonesia 2017.Peraturan Menteri Agraria dan Tata Ruang/ 
Hengky, Gunawan, Pelayanan Pendaftaran Hak Atas Tanah 269

Kepala BPN No. 4 Tahun 2017 tentang Standar Pelayanan Kementrian Agraria dan Tata Ruang/BPN

Negara Republik Indonesia 2018 .Peraturan Menteri Agraria dan Tata Ruang/ Kepala BPN Republik Indonesia Nomor 6 Tahun 2018 tentang Pendaftaran Tanah Sistematis Lengkap

\section{Website}

www.bpn.go.id

www.kab-sintang.artbpn.go.id 